\title{
Large-scale lysimeter site St. Arnold, Germany: analysis of 40 years of precipitation, leachate and evapotranspiration
}

\author{
N. Harsch ${ }^{1}$, M. Brandenburg ${ }^{2}$, and O. Klemm ${ }^{1}$ \\ ${ }^{1}$ Institute of Landscape Ecology, University Münster, Germany \\ ${ }^{2}$ State Office for Nature, Environment and Consumer Protection, Germany \\ Received: 25 July 2008 - Published in Hydrol. Earth Syst. Sci. Discuss.: 9 September 2008 \\ Revised: 3 December 2008 - Accepted: 24 February 2009 - Published: 11 March 2009
}

\begin{abstract}
This study deals with a lysimetricalmeteorological data series collected on the large-scale lysimeter site "St. Arnold", Germany, from November 1965 to April 2007. The particular relevance of this data rests both upon its perdurability and upon the fact that the site is comprised of a grassland basin, an oak/beech and a pine basin.
\end{abstract}

Apart from analyzing long term trends of the meteorological measurements, the primary objective of this study is to investigate the water balance in grassland and forested basins, in particular comparing the precipitation term to leachate quantities and potential and actual evapotranspiration. The latter are based upon the Penman and the Penman-Monteith approaches, respectively.

The main results of this survey are that, on a long-term average, the grassland basin turns more than half $(53 \%)$ of its annually incoming precipitation into leachate and only $36 \%$ into water vapour, while the deciduous forest exhibits a ratio of $37 \%$ for leachate and $56 \%$ for evapotranspiration, and the evergreen coniferous forest shows the highest evaporation rate $(65 \%)$ and the lowest leachate rate $(26 \%)$.

Concerning these water balances, considerable differences both between basins and between seasons stand out. While summer periods exhibit high evapotranspiration rates for the forests and moderate ones for the grassland, winter periods are characterised by considerable leachate quantities for grassland and the deciduous forest and moderate ones for the coniferous forest. Following the analysis of the climatic development in St. Arnold, trends towards a milder and more humid regional climate were detected.

Correspondence to: N. Harsch

(nina.harsch@gmail.com)

\section{Introduction}

Europe is in possession of about 2450 lysimeters, 1260 of them being located in Germany (cp. Lanthaler, 2006). As of 2006, leading varieties in lysimetrical research are fields (63\%) and grassland (21\%), while just very few European lysimeters are used for investigations about fallow land $(6 \%)$, forests $(1 \%)$ or other $(4 \%)$. Of the 1260 German lysimeters, only about 15 are planted with forest, 4 of those on large scale basins. Hence, due to its rarity, especially lysimetrical forest data like the one of St. Arnold has to be rated as particularly valuable (cp. Lanthaler, 2006).

Due to the growing importance of hydrological topics for an efficient water resource management and better understanding of the water cycle, this paper is meant to give a deeper insight into the water balance of grassland in comparison to deciduous and coniferous forest, in this case represented by Quercus robur (English Oak), Fagus silvatica (European Beech) and Pinus strobus (Eastern White Pine).

Research venue is the large-scale lysimeter site St. Arnold $\left(52^{\circ} 13^{\prime} 06^{\prime \prime} \mathrm{N}, 7^{\circ} 23^{\prime} 24^{\prime \prime} \mathrm{E}\right.$, height above sea level: $52 \mathrm{~m}$ ), located in North Rhine-Westphalia, Germany. The site, which records both meteorological and lysimetrical data on a daily basis, is now administered by the State Office for Nature, Environment and Consumer Protection of Northrhine Westphalia (LANUV NRW) and was commissioned in November 1965 by the Office for the Environment (Staatliches Umweltamt Münster). It consists of three monolithically filled, non-weighable lysimetrical basins made of ferroconcrete and without groundwater contact, each incorporating a surface area of $20 \times 20 \mathrm{~m}^{2}$ and a depth of $3.5 \mathrm{~m}$ and being covered with the forecited vegetational layers. In all three cases, the water sampling takes place on a zero-tension basis, the soil type is a medium-sandy podzol, and the vegetation is in reasonable condition, although, as a result of the

Published by Copernicus Publications on behalf of the European Geosciences Union. 
winter gale "Kyrill", the stock figure of the coniferous forest decreased conspicuously in January 2007. The grass on the grassland basin is cut three to six times per year and, in order to eliminate moss, also gets verticutted twice per year. Below each basin, a leachate collecting vessel, holding up to 4001 , is being metered daily. Beside leachate and vegetational development measurements, St. Arnold also collects daily data on air temperature, precipitation, global radiation, sunshine duration, relative humidity, wind speed and tree development, thus providing excellent premises for water balance studies.

To date several studies have focused on St. Arnold, numerous of them accomplished by Schroeder $(1975,1976,1983$, 1984, 1987-1989, 1990, 1992) who investigated about various aspects of the water cycle, e.g., precipitation, leachate quality, groundwater recharge, interception loss and potential and actual evapotranspiration. Other surveys were conducted by Wesseling et al. (1991), Weiss (1992), Klein (2000) and Graf et al. (2006), dealing with soil acidification, climatological trends, evapotranspiration and water balance modelling.

This study is assigned to perpetuate the henceforth 40 years of investigation conducted on the large scale lysimeter site St. Arnold. The focus lies on the water balance, the comparison of the differently planted basins, data quality assessment, and the identification of trends over the 40 years of uninterrupted measurement.

\section{Methods}

Apart from the before mentioned meteorological, vegetational and lysimetrical measurement values, this study also incorporates calculated values of the potential evapotranspiration (PET) and the actual evapotranspiration (AET), determined by the approaches of Penman (1948) and PenmanMonteith (1965). The measurement values mandatorily required for these calculations are air temperature, wind speed, relative humidity, sunshine duration, plus, in case of the AET, leaf area indexes (LAI), tree heights and measurement heights of wind speed and relative humidity.

The Penman equation is as follows:

$P E T=\frac{\Delta}{\Delta+\gamma} \times \frac{Q_{S}-B}{L}+\frac{\gamma}{\gamma+\Delta} \times f(U) \times \frac{e^{*}-e}{L}(1)$

with $\Delta$ as the slope of the saturated vapour pressure versus temperature curve, $\gamma$ as the psychrometer constant, $\mathrm{Q}_{s}$ as the net radiation, $\mathrm{B}$ as the soil heat flux ${ }^{1}, \mathrm{~L}$ as the latent heat of evaporation, $\mathrm{f}(\mathrm{U})$ as the transfer coefficient for water vapour, $\mathrm{e}^{*}$ as the vapour pressure at saturation and $\mathrm{e}$ as the actual vapour pressure.

The Penman-Monteith equation is as follows:

$$
A E T=\frac{\Delta \times\left(Q_{S}-B\right)+\delta \times c_{p} \times \frac{e^{*}-e}{r_{a}}}{L \times \gamma \times\left(1+\frac{r_{s}}{r_{a}}\right)}
$$

\footnotetext{
${ }^{1}$ On a yearly basis, the soil heat flux averages around zero and can thus be disregarded (cp. Ayana Gebul, 2001).
}

with $\Delta, \gamma, \mathrm{Qs}, \mathrm{B}, \mathrm{L}, \mathrm{e}^{*}$ and $\mathrm{e}$ as in Eq. (1) and with $\rho$ as air density, $\mathrm{c}_{p}$ as the specific heat capacity of humid air under constant pressure, $\mathrm{r}_{a}$ as the aerodynamic resistance and $\mathrm{r}_{s}$ as the stomatal resistance.

As quoted above, the determination of the stomatal resistance requires information on the LAI. Yet, calculating the AET for short vegetation (and grassland, respectively), $r_{a}$ and $\mathrm{r}_{s}$ can be avoided by using linear regressions for the ventilation of humidity over grassland:

$E_{a}=a \times(b+c \times u) \times\left(e^{*}-e\right)$

with $\mathrm{a}, \mathrm{b}, \mathrm{c}$ as parameters slightly varying in literature, $\mathrm{u}$ as the wind speed and $\mathrm{e}^{*}$ and $\mathrm{e}$ as in Eq. (1).

According to Baumgartner and Liebscher (1990), a, b and $\mathrm{c}$ are the following:

$\mathrm{a}=0,35 ; \mathrm{b}=0,50 ; \mathrm{c}=0,54$

The application of this regression to the Penman formula hence produces the Penman formula for short vegetation:

$A E T_{s v}=\frac{\Delta \times \frac{Q_{s}-B}{L}+\gamma \times E_{a}}{\Delta+\gamma}$

One of the most interesting issues in lysimetry is to estimate the branching of available precipitation water into evapotranspiration and leachate. It is intriguing to compute averages for the various types of management. In the case of St. Arnold, this seems most easy for the grassland, as its boundary conditions are more or less constant and the variability between years is mostly driven by meteorology. For the forest stands, however, the growth of the vegetation (see below for details) is likely to lead to a general trend, so that general means or ratios (leachate/precipitation and AET/precipitation) may be void. Thus, in order to obtain reliable results, stationarity of conditions must be checked first. To do this, the following steps were taken:

1. Calculation of ratios of leachate/precipitation and AET/precipitation for each year and each basin (grassland: 1966-2006; forests: $1980^{2}-1999^{3}$ ).

2. Calculation of means for each type of ratio and each basin.

3. Calculation of relative standard deviations (RSD) for each type of ratio, each basin and both time periods (grassland only).

Table 1 demonstrates that the RSD of the branching ratios for the two forests are in the same order as those for the

\footnotetext{
${ }^{2}$ Due to the particularly strong growth of the trees during the first decade of the measuring period, which would provoke an adulteration of the results of the mean values, the forest data was only taken as of 1980 .

${ }^{3}$ Due to the missing LAI data as of 2000 , the forest values could only be taken until 1999 .
} 
Table 1. Relative Standard Deviations of L/P and AET/P ratios for grassland and forests.

\begin{tabular}{lllll}
\hline & \multicolumn{2}{l}{ Relative Standard Deviation (leachate/precipitation) } & Relative Standard Deviation (AET/precipitation) \\
\hline & $1966-2006$ & $1980-1999$ & $1966-2006$ & $1980-1999$ \\
Grassland & 0.18 & 0.19 & 0.28 & 0.22 \\
Oak/Beech Forest & - & 0.29 & - & 0.25 \\
Pine Forest & - & 0.30 & - & 0.21 \\
\hline
\end{tabular}
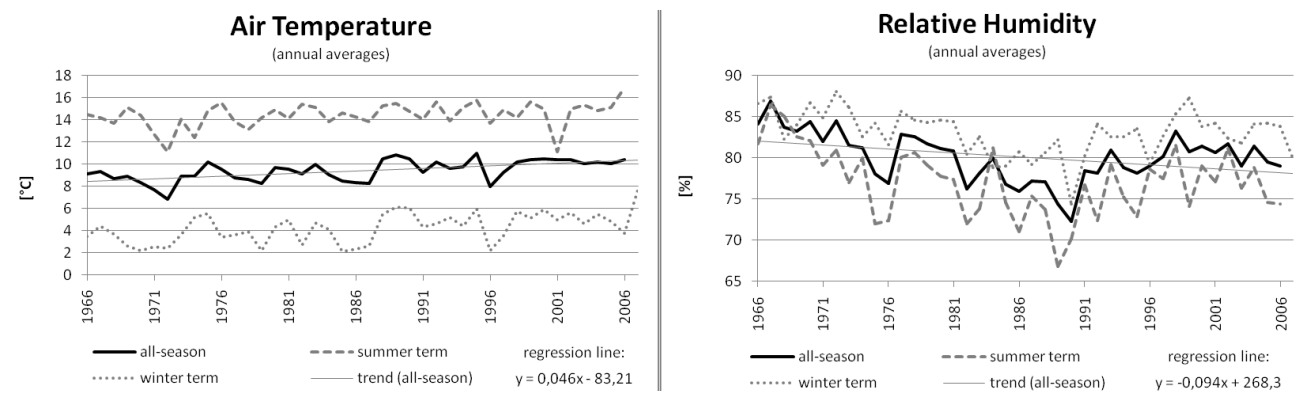

Fig. 1. Development of air temperature and relative humidity in St. Arnold from 1966 to 2007.

grassland. This indicates that, for the 20-year period, their inter-annual variability is not dominated by trends but rather driven by the variability of meteorological conditions. This leads to the conclusion that average branching ratios can be stated both for the grassland and the two forest lysimeters. The ratios are, however, not to be interpreted as typical for oak/beech or pine forests in central Europe, but represent the lysimeter site St. Arnold with tree stands of about 15-30 years of age and 5-15 $\mathrm{m}$ stand height.

\section{Data sets}

The data sets used for this survey mostly comprise daily values from 1 November 1965 through 30 April 2007. All data is treated by hydrological definition viz., winter periods begin on 1st November and summer periods on 1st May. Daily values are accordingly totalled and averaged. Concerning trends, unless denominated as "insignificant", all regression lines comply with a confidence interval of $95 \%$ and are thus statistically significant (q.v. Cislaghi et al., 2005). The assessment technique applied for trend determination was in all cases a simple linear regression with the time axis as the independent variable.

Figures 1, 2 and 3 present the annual and biannual developments of the meteorological data collected in St. Arnold from 1966 through 2007. All measuring devices are located directly adjacent to the grassland basin and therefore primarily represent this area. Nevertheless, their data also formed a basis for the calculation of evapotranspiration of the forest basins.
- Air Temperature (Fig. 1): The temperature measurement is conducted with a thermograph at a height of $2 \mathrm{~m}$ above ground level. Yearly averages vary from a minimum of $6.8^{\circ} \mathrm{C}$ in 1972 to a maximum of $11^{\circ} \mathrm{C}$ in 1995, and show a slight upward trend with a gradient of $0.05^{\circ} \mathrm{C} / \mathrm{a}$. While the long term average determined by Schroeder in 1992 was still at $9.0^{\circ} \mathrm{C}$, it is now computed as $9.4^{\circ} \mathrm{C}$. Comparing seasons, the mentioned upward trend can be identified more clearly in winter than in summer periods, that is to say that predominantly due to warmer winters, the climate in St. Arnold has become slightly milder over the years. This development reflects the forecast for Germany released by the German Meteorological Service in 2001 (cp. Rapp, 2001).

- Relative Humidity (Fig. 1): Relative Humidity is measured with an aspiration psychrometer and, like the air temperature, recorded at $2 \mathrm{~m}$ height above ground level. The minimum annual value observed between 1966 and 2007 emerged in 1990 at $72 \%$ and the maximum in 1967 at $87 \%$. Trends are slightly negative, with a gradient of $-0.09 \% / a$ for the annual averages and more pronounced for summer than for winter periods. Due to the temperature difference, the former show lower average values for relative humidity than the latter.

- Sunshine Duration (Fig. 2): The sunshine duration in St. Arnold is plotted by a Campbell-Stokes sunshine chart recorder at a height of $6 \mathrm{~m}$ above ground level. During the observation period, the annual sums ranged between $938 \mathrm{~h} / \mathrm{a}$ (1981) and 1796 h/a (2003), with an overall average of $1335 \mathrm{~h} / \mathrm{a}$. There is an annual upward 

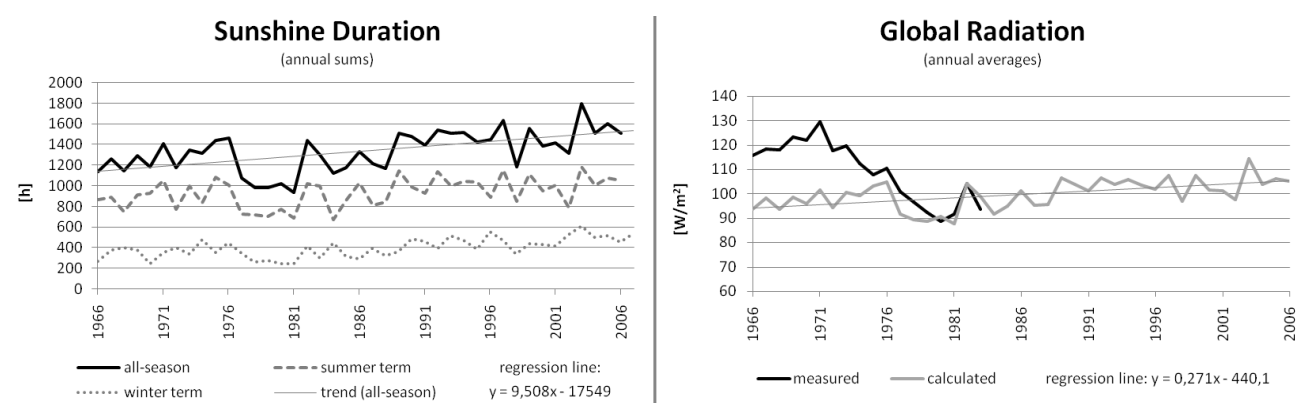

Fig. 2. Development of sunshine duration and global radiation in St. Arnold from 1966 to 2007.
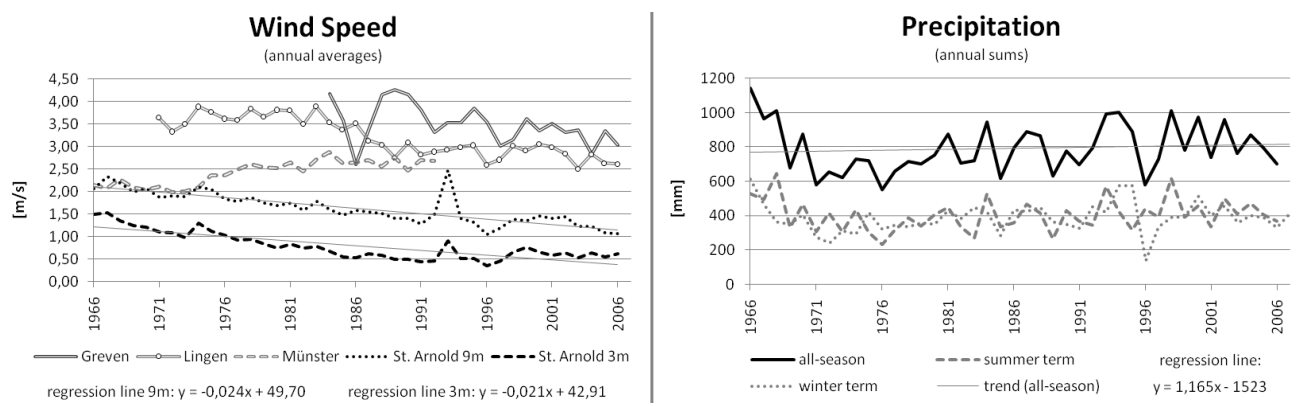

Fig. 3. Development of wind speed and precipitation in St. Arnold (and neighbouring sites) from 1966 to 2007.

trend with a gradient of $9,5 \mathrm{~h} / \mathrm{a}$, almost equally dispersed between summer and winter periods. Regarding the yearly patterns, Schroeder (1992) observed a positive correlation between sunshine duration and relative humidity.

- Global Radiation (Fig. 2): Until 1997, the incoming short wave radiation in St. Arnold was measured analogly by a Robitzsch radiation chart recorder which was subsequently replaced by a digitally recording solarimeter. As only the data from 1966 to 1983 could be retrieved for this survey, global radiation was additionally assessed from the sunshine duration data, using a regression equation developed by Kohsiek (1971) in conjunction with the Angström method (cp. e.g. Sahin 1998). These computed results were compared to the measured data. Although there are discrepancies of 20$30 \mathrm{~W} /\left(\mathrm{m}^{2} * \mathrm{a}\right)$ during the first 8 years, as from 1975 to 1983 , both charts show a fairly similar tendency. A reason for the discrepancies might be based on the fact that the regression equation does not incorporate the tree development. Due to the initially low height of the forests, the measured global radiation exhibits relatively high values at the onset and then, in analogy to the growth process of the trees, continually decreases until finally reaching similar values as the calculated global radiation data. Thus, for the period of 1984 to 2007, all evapotranspiration values mentioned in this survey are based upon the calculated global radiation data.

\section{Quantity of trees}

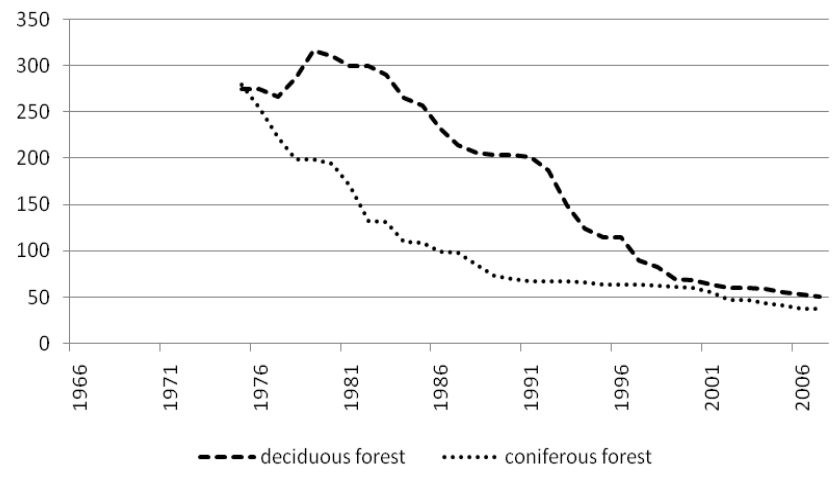

Fig. 4. Quantity of trees in St. Arnold from 1966 to 2007. The deciduous forest consists of Quercus robur (English Oak) and Fagus silvatica (European Beech) and the coniferous forest of Pinus strobus (Eastern White Pine).

Concerning the long term development of the global radiation, the calculated data shows a long term average of $99 \mathrm{~W} /\left(\mathrm{m}^{2} * \mathrm{a}\right)$ and an upward trend of $0,30 \mathrm{~W} /\left(\mathrm{m}^{2} * \mathrm{a}\right)$, while the measured data, after its relatively strong decline until 1980 , settles down at an average of $95 \mathrm{~W} /\left(\mathrm{m}^{2} * \mathrm{a}\right)$.

- Wind Speed (Fig. 3): Regarding the wind speed it must be pointed out that, albeit qualitatively unobjectionable, the data collected in St. Arnold has to be handled with care in the calculation of potential evapotranspiration, 

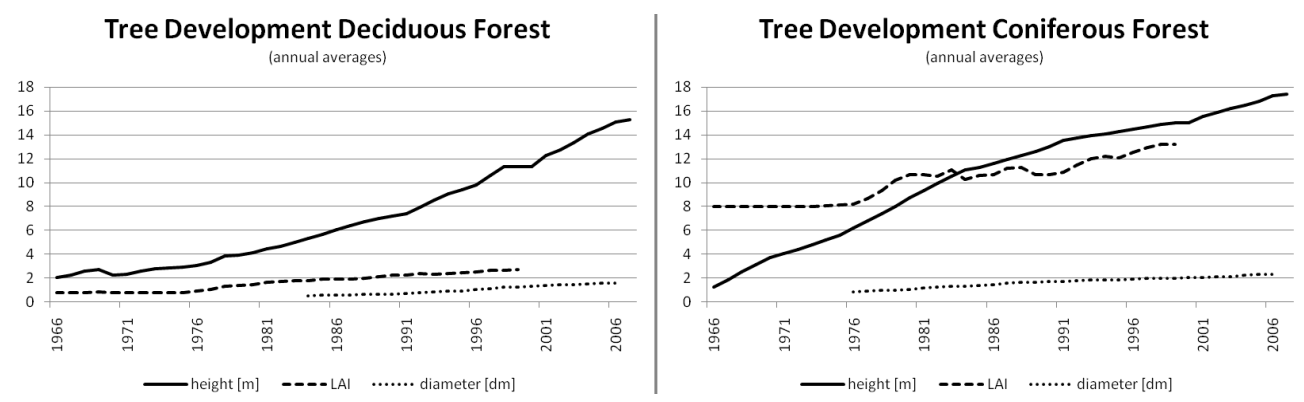

Fig. 5. Height, leaf area index (LAI) and diameter of trees in St. Arnold from 1966 to 2007.

using the Penman approach. Due to the sheltered location of the lysimeter site (it is almost entirely surrounded by mature forest), wind speeds in St. Arnold are considerably lower than they would be under Penman's precondition of an "extended surface of green crop" (cp. Klein, 2000). In order to avoid errors in this matter, external wind speed data from circumjacent meteorological stations ${ }^{4}$ was averaged and thus integrated into the calculation of potential evapotranspiration in this survey. In order to coevally reflect the actual situation in St. Arnold, the original wind speed data (measured in $9 \mathrm{~m}$ height above ground) was used in the determination of actual evapotranspiration.

The wind speed chart in Fig. 3 illustrates the differences between the values obtained in the meteorological stations and in St. Arnold at heights of $3 \mathrm{~m}$ and $9 \mathrm{~m}$ (measured with contact anemometers). While the values of the meteorological stations average out at $3,0 \mathrm{~m} / \mathrm{s}$, the values of St. Arnold in $3 \mathrm{~m}$ and $9 \mathrm{~m}$ height average out at $1 \mathrm{~m} / \mathrm{s}$ and, as a result of the increasing tree heights (q.v. Fig. 5), show annual downward trends of $-0,021 \mathrm{~m} /\left(\mathrm{s}^{*} \mathrm{a}\right)$ in the case of $3 \mathrm{~m}$ height and of $-0,024 \mathrm{~m} /\left(\mathrm{s}^{*} \mathrm{a}\right)$ in the case of the measurement effected in $9 \mathrm{~m}$ height.

- Precipitation (Fig. 3): In order to avoid measurement losses due to high wind speeds ${ }^{5}$, precipitation in St. Arnold is measured within ground level with a Hellmann pluviometer. As visible in Fig. 3, it shows considerable annual variations ranging from $552 \mathrm{~mm}$ in 1976 to $1140 \mathrm{~mm}$ in 1966 . While the long term precipitation average for Germany amounts to $750 \mathrm{~mm} / \mathrm{a}$ (cp. Albrecht, 2001), St. Arnold averages out at $791 \mathrm{~mm} / \mathrm{a}$. The outstandingly high value in 1966 was reappraised by Klein (2000) who compared it with data from the nearby

\footnotetext{
${ }^{4}$ German Meteorological Service (Deutscher Wetterdienst), station 1153 (Münster), station 1151 (Greven) and station 1132 (Lingen).

${ }^{5}$ According to Sevruk (1981), a precipitation measurement performed at a height of merely $1 \mathrm{~m}$ already produces a measuring fault of about $5-10 \%$, compared to a measurement on ground level.
}

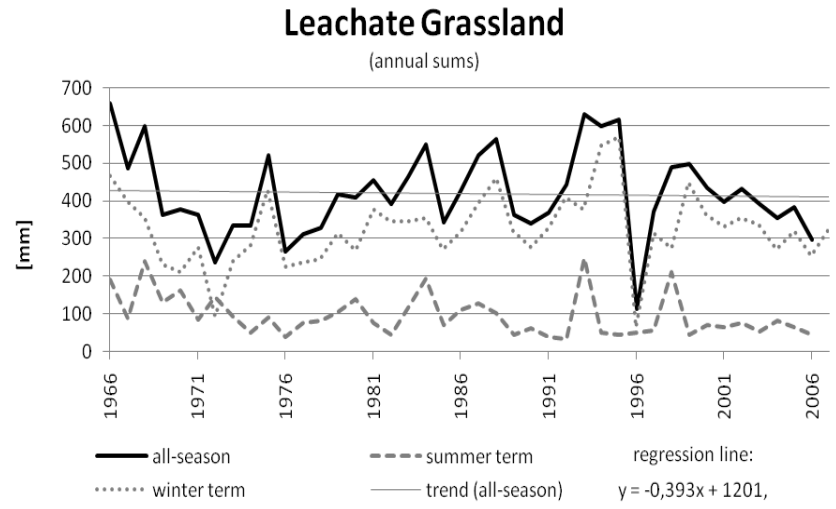

Fig. 6. Development of leachate from grassland in St. Arnold from 1966 to 2007.

meteorological station Greven and obtained the same result. Although showing such a high value at the onset, the annual precipitation sums in St. Arnold are subject to a slight upward trend with a gradient of $1.2 \mathrm{~mm} / \mathrm{a}$. However, given the inter- and intra-annual variability, this trend is insignificant. Another interesting observation in this context is that the precipitation heights of the summer periods often outrange those of the winter periods. Taking a closer look at the daily data, it becomes clear that this mainly ascribes to the fact that, especially during the last decade, intense rain events have become much more frequent during summer than during winter periods. A study conducted by Böwer (2007) about regional climate change in North Rhine-Westphalia confirms this and suggests that it particularly applies to the autumnal months of the hydrological summer periods.

Figures 4 and 5 demonstrate the tree development on the two forest basins in St. Arnold.

Regarding tree quantities (Fig. 4), the provided data only ranges from 1976 to 2007, but according to Schroeder (1992), a plantation of several new deciduous trees took place in 1970. This causes the slight diminishment of the average tree height curve in the deciduous forest chart (Fig. 5) in the said year. According to the available tree quantity data, 

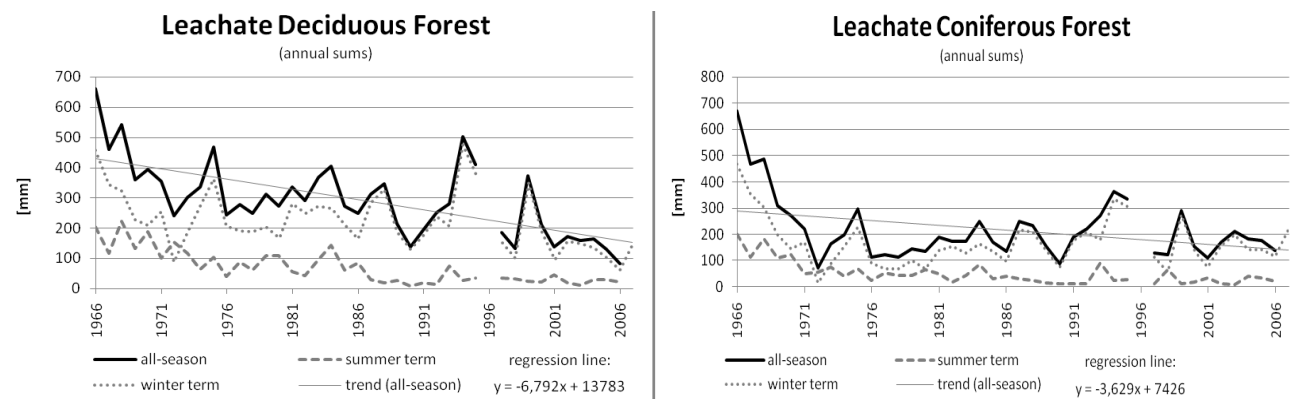

Fig. 7. Development of leachate from deciduous and coniferous forest in St. Arnold from 1966 to 2007.

a strong decrease from 275 deciduous and 280 coniferous trees in 1976 to merely 51 deciduous and 37 coniferous trees in 2007 took place. Reasons for this are the natural decease of weak trees in the case of the oak/beech forest and professional thinnings in case of the pine forest (cp. Schroeder, 1992). Moreover, severe gale events such as "Verena" in 1993 (cp. wind speed chart in Fig. 3) and the aforementioned "Kyrill" in 2007 provoked losses in the stock figures.

Comparing the tree development charts in Fig. 5, the different growth processes of the two forest types stand out. While the deciduous forest pursues a slowly accelerating growth scheme, the coniferous forest is subject to an initially rapid growth, slowing down over the years. This pattern is furthermore reflected in the increase in diameters. While the latter are disregarded within the Penman-Monteith calculation of actual evapotranspiration, tree heights and, in addition, leaf area indexes (LAI), are required. Being deciduous and hence defoliate during half of the year, the oak/beech forest exhibits a much lower LAI (1-3) than the evergreen pine forest with its large total needle surface (LAI 8-13). The LAI values used in this survey were provided by the University of Osnabrück and emanate from both leaf litter countings, a light profile measurement carried out in 1999 and the adoption of estimator functions by Deblonde (1994) and Fulton (1993).

Figures 6 and 7 represent the annual and biannual leachate quantities measured on the three lysimeter basins in St. Arnold. While the low growing grassland shows an average infiltration rate of $420 \mathrm{~mm} / \mathrm{a}$, the deciduous oak/beech forest produces $295 \mathrm{~mm} / \mathrm{a}$ and the pine forest merely $217 \mathrm{~mm} / \mathrm{a}$, which attributes to the fact that its needles provide an all-seasonal shelter from precipitation.

All basins exhibit long term downward trends, but as a result of the rising tree heights, the leachate quantities of the forests decrease much more than those of the grassland. The downward trend of the grassland basin merely amounts to $-0.4 \mathrm{~mm} / \mathrm{a}$ and is insignificant. The trend of the deciduous forest basin amounts to $-6.8 \mathrm{~mm} / \mathrm{a}$ and of that the coniferous forest basin to $-3.6 \mathrm{~mm} / \mathrm{a}$.

Concerning seasons, winter periods produce almost the entire annual leachate amounts. Summer periods record av- erages of merely $95 \mathrm{~mm} / \mathrm{a}$ for grassland, $70 \mathrm{~mm} / \mathrm{a}$ for the oak/beech forest and $51 \mathrm{~mm} / \mathrm{a}$ for the pine forest.

The results of the calculated evapotranspiration values will be discussed in-depth within the following section (cp. Figs. 10 and 11). Due to the missing LAI data as of 2000, the actual evapotranspiration of the forest basins could only be calculated for the period of 1966 to 1999 . While the PET in St. Arnold averages at $578 \mathrm{~mm} / \mathrm{a}$, the long term AET of the grassland amounts to $283 \mathrm{~mm} / \mathrm{a}$, that of the deciduous forest to $351 \mathrm{~mm} / \mathrm{a}$ and that of the coniferous forest to $440 \mathrm{~mm} / \mathrm{a}$. With exception of the grassland, all evapotranspiration curves exhibit long term upward trends. Those amount to $11.1 \mathrm{~mm} / \mathrm{a}$ in case of the deciduous forest, to $8.4 \mathrm{~mm} / \mathrm{a}$ in case of the coniferous forest and to $5.0 \mathrm{~mm} / \mathrm{a}$ in case of the PET. Concerning the grassland AET, the trend amounts to $-1.3 \mathrm{~mm} / \mathrm{a}$. It is furthermore noticeable that the AET rates are significantly lower in winter than in summer periods. This especially applies to the deciduous forest which produces a biannual average of $323 \mathrm{~mm}$ during estival and a mere $28 \mathrm{~mm}$ during hibernal seasons.

\section{Results and discussion}

As precipitation, leachate and evapotranspiration form the central part of the water cycle, this paragraph is meant to give a more detailed look into the long term trends and characteristics of these three variables in St. Arnold. Unfortunately, no data of throughfall and stemflow was available, so that canopy interception could not be estimated.

Figures 8 and 9 compare the annual and biannual development of the three leachate varieties and the gross precipitation measured in St. Arnold from 1966 to 2007.

Examining the leachate curves in the annual chart (Fig. 8), the development of the two forests and their abovementioned diverse growth schemes become obvious. Because of the initially low tree heights, the three basins show only little difference in leachate quantities during the first 4 years. From 1969 onwards, they begin to take dissimilar paths: Whereas the fast growing, evergreen pine forest directly declines its leachate sums, while the more temperately growing oak/beech forest aligns with the grassland until 1976 and 


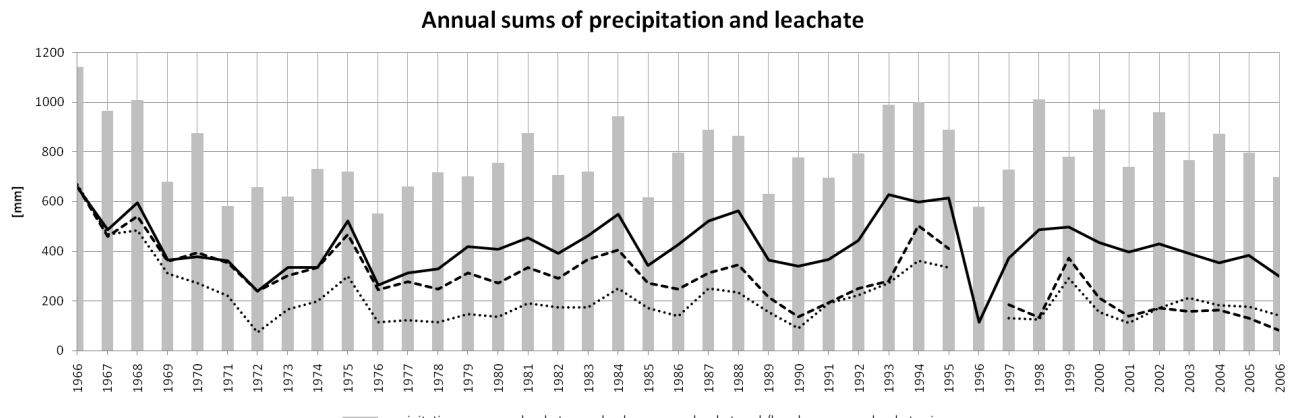

Fig. 8. Annual sums of leachate and gross precipitation in St. Arnold from 1966 to 2006.

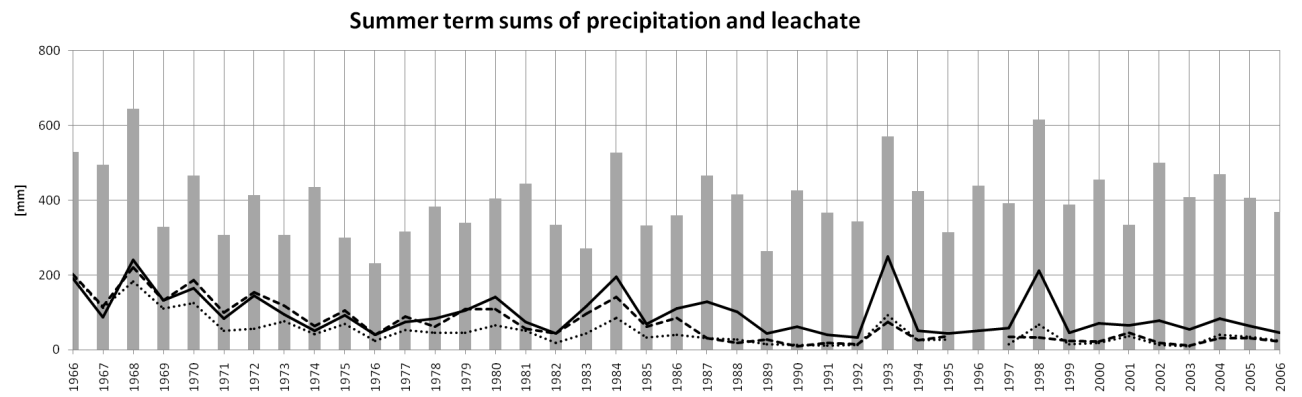

- precipitation —leachate grassland -----leachate oak/beech ….... leachate pine

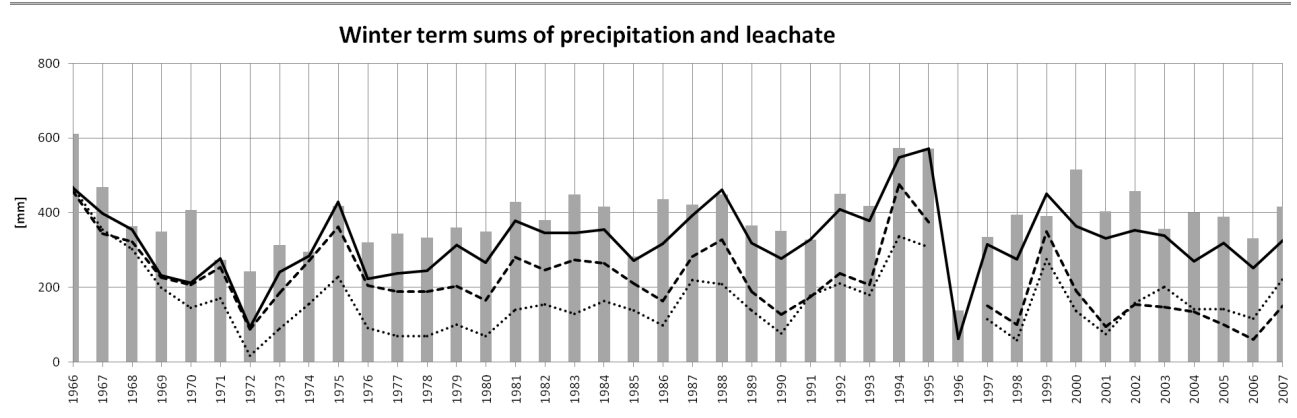

Fig. 9. Biannual sums of leachate and gross precipitation in St. Arnold from 1966 to 2007.

then slowly decreases its leachate quantities. As of 1990, the forests seem to have reached similar canopy closures, that is, their annual leachate sums converge again, this time being clearly outbalanced by the grassland.

Apart from the forest growth aspect, the decisive role regarding leachate quantities is naturally being played by precipitation. As visible in Figure 8, particularly the grassland basin exhibits a clear correlation between precipitation and leachate sums. Nevertheless, in the case of St. Arnold, the grassland basin is neighbored by the two forest basins (at two sides) on the one hand, and the forest which surrounds the entire lysimeter area (at the other two sides) on the other hand. This leads to the forecited slight diminishment in leachate quantities over the years (cp. Fig. 6). The shelter provided by the tree populations hence provokes a slight distortion of the leachate rates measured on grassland. This shelter also affects the actual evapotranspiration rates of the grassland basin (cp. Fig. 10), causing them to exhibit the aforementioned slight downward trend.

On annual average ${ }^{6}, 53 \%$ of the gross precipitation measured in St. Arnold percolate into the grassland basin, 37\% into the deciduous and $26 \%$ into the coniferous forest basin. Comparing this to the biannual charts (Fig. 9), it becomes apparent that although hibernal and estival precipitation quantities are rather similar, the leachate curves of the two forests show considerably lower rates for summer periods. This attributes to the fact that both air temperature and tree water demand are articulately higher during the vegetation period. Consequently, evapotranspiration increases and leachate is

\footnotetext{
${ }^{6}$ Averages: 1969-2006 for grassland and 1980-1999 for forests (cp. Table 1).
} 


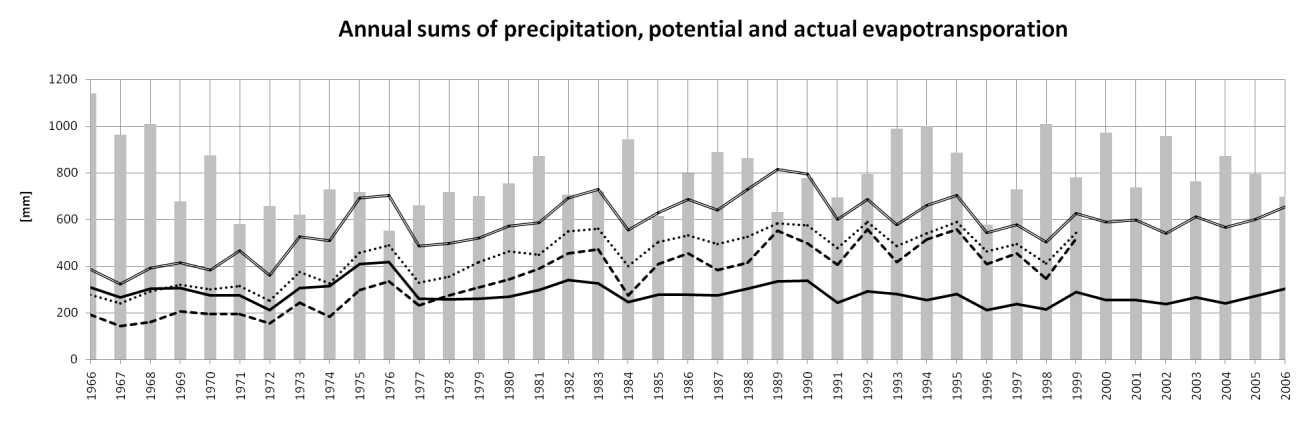

Fig. 10. Annual sums of evapotranspiration and gross precipitation in St. Arnold from 1966 to 2006.

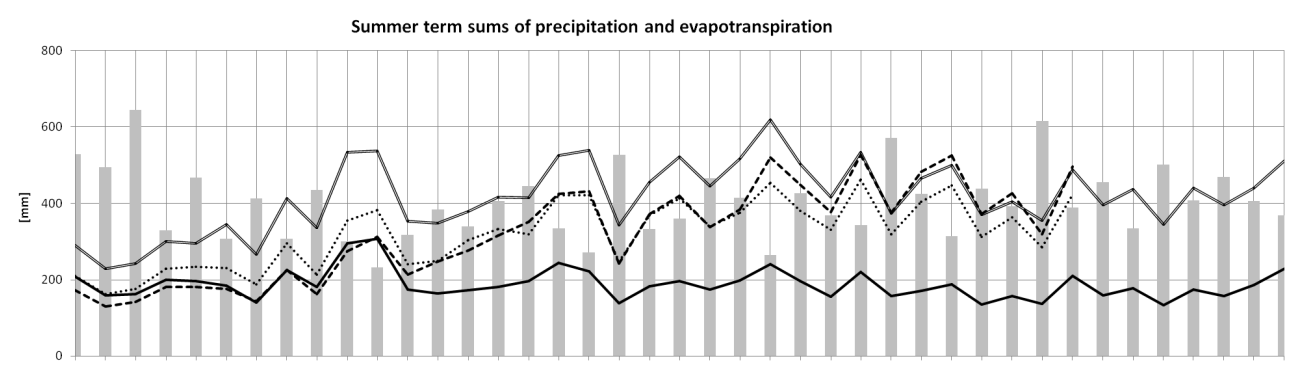

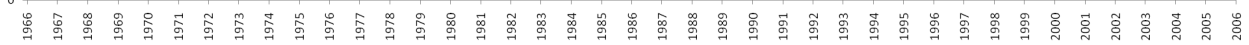

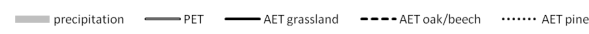

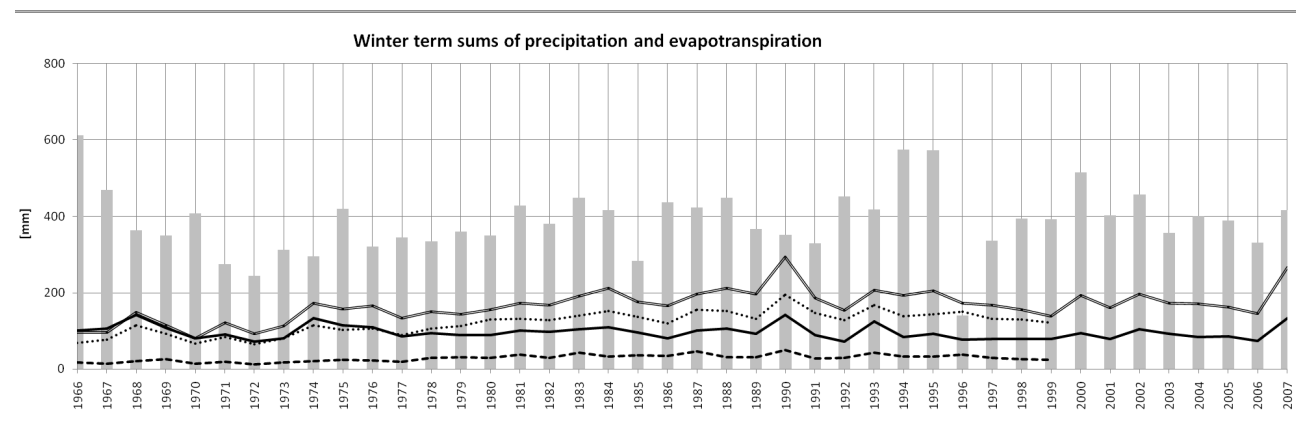

- precipitation —PET — AET grassland --.--AET oak/beech …… AET pine

Fig. 11. Biannual sums of evapotranspiration and gross precipitation in St. Arnold from 1966 to 2007.

reduced (q.v. surveys by Barsch and Flügel, 1988 and Zirlewagen, 2002).

Figures 10 and 11 represent the long term annual and biannual developments of evapotranspiration and precipitation in St. Arnold.

Analogously to the leachate development in Fig. 8, the growth process of the trees is equally reflected in the annual AET rates (Fig. 10). While the grassland is subject to constantly low evapotranspiration rates with the slight downward trend commented on above, the growing forests exhibit perennial AET increases, whereas the evergreen pines at all times outbalance the deciduous oaks and beeches. Salihi (1984) determined the water balance of an oak/beech and a pine forest in Eastern Germany over a period of 15 years and observed that the annual AET rates of the coniferous forest almost consistently outbalanced those of the deciduous for- est by $19 \%$. In St. Arnold, this ratio amounts to 11 to $25 \%$, depending on tree ages/heights.

Examining the forest development in St. Arnold, it is furthermore noticeable that during the first 10 years of the observation period, the AET sums of the deciduous forest are lower than those of the grassland. Reasons for this discrepancy might be the initially minor canopy closure of the former, causing more precipitation to drain away than on grassland.

In contrast to leachate, evapotranspiration does not show much connection to the precipitation sums. This might be based upon the more complex relations: While (under moderately humid conditions) leachate is almost directly connected to precipitation, evapotranspiration depends much more strongly on meteorological parameters such as temperature, sunshine duration, relative humidity, global radiation 


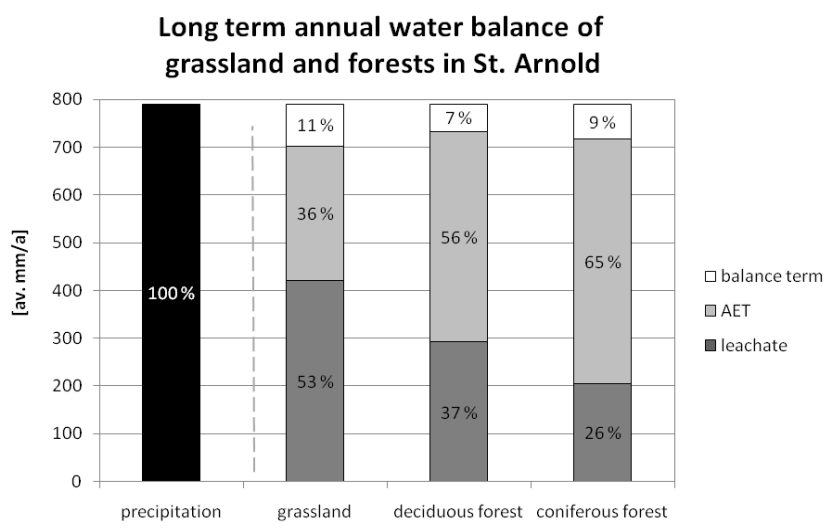

Fig. 12. Long term annual water balance of grassland (1966-2006) and forests (1980-1999) in St. Arnold.

and wind speed (q.v. Steiner et al., 1991). Möller and Stanhill (2007) investigated about this aspect comparing the AET and precipitation of a site with a humid climate in Ireland to a site with a semi-arid climate in Israel, finding that correlations between these two variables solely occur during periods of water stress. Yet, as this never occurred in St. Arnold, there is hardly any likeliness for such correlations. In fact, with annual precipitation rates of at least $550 \mathrm{~mm} / \mathrm{a}$, even rather dry years in St. Arnold (e.g. 1976, 1985, 1989, Fig. 10) still provide sufficient humidity for regular or even slightly elevated evapotranspiration rates.

A further-reaching point in this context was made by Salihi (1984), who closely analysed the AET and precipitation rates of forests during extreme years and observed that not only extremely arid (cp. supra, Möller and Stanhill, 2007) but also extremely humid years can produce AET rates below average. While the former lack the water, the latter are stressed by its surplus and thus lack the energy required for evapotranspiration (q.v. Stephenson, 1990). Furthermore, the under such conditions reduced vapour pressure gradient $\left(e^{*}-e\right)$ might be another reason for low evapotranspiration rates. Examining the precipitation rates in St. Arnold (Fig. 10), with 1984, 1993 and 1998 as particularly humid years $(>940 \mathrm{~mm} / \mathrm{a})$, it stands out that the corresponding AET sums indeed show relatively low values $(<260 \mathrm{~mm} / \mathrm{a}$, whereas the long term forest AET averages amount to 350$450 \mathrm{~mm} / \mathrm{a}$ ).

With regard to average evapotranspiration values, St. Arnold conforms with the results of comparable surveys. Ladekarl (2001), for instance, evaluated evapotranspiration rates of different forest sites in Europe (Denmark, France, Germany, United Kingdom) and found average values of $420-490 \mathrm{~mm} / \mathrm{a}$ for oak forests and $487-655 \mathrm{~mm} / \mathrm{a}$ for beech forests. With a long term AET average of $351 \mathrm{~mm} / \mathrm{a}$ for the oak/beech basin, St. Arnold is classed considerably lower, but it also has to be regarded that this value represents the entire and still uncompleted growth process of the forest. Comprising only the last 10 years of the observation period, the deciduous forest in St. Arnold shows an average of $475 \mathrm{~mm} / \mathrm{a}$ and thus already corresponds with the rates compiled by Ladekarl (2001). Nevertheless, it has most likely not reached its upper limit yet.

Comparing seasons (Fig. 11), the influence of the air temperature on evapotranspiration becomes evident. Although precipitation is sufficiently provided at almost all times, temperature differences cause the evapotranspiration rates to be lower during hibernal and higher during estival seasons. Next to this, autumnal leaf loss naturally plays a major role regarding evapotranspiration quantities. On account of its thereby strongly reduced evapotranspirational surface, the deciduous forest shows the aforementioned extremely low AET rates during winter periods. During summer periods, the opposite occurs. While the grassland AET shows rather regular, constantly low values, the AET rates of the forests increase significantly and occasionally even reach similar heights as the PET (cp. summer period chart, Fig. 11). Regarding the AET rates of the forests during estival terms, it is furthermore noticeable that the AET of the deciduous forest occasionally outbalances the one of the coniferous forest. This takes place especially during relatively dry summers (e.g. 1989, 1996) and is based upon the fact that deciduous trees tend to root much deeper than coniferous trees and thus exhibit a significantly higher tolerance to dry conditions (cp. Klein, 2000). Thus it becomes obvious that apart from climatological aspects, the water cycle is also strongly controlled by soil specific (cp. Fayer et al., 2006) and vegetational (cp. Scanlon et al., 2005) aspects.

According to Zenker (2003), about $60 \%$ of the annual precipitation in Central Europe returns into the atmosphere through evapotranspiration. Figures 12 and 13 illustrate the long term annual and biannual water balances of the three lysimeter basins in St. Arnold, based upon the following water balance equation (cp. Milly 1994):

$\mathrm{P}=\mathrm{L}+\mathrm{AET}+\mathrm{B}$

with $\mathrm{P}$ as precipitation, $\mathrm{L}$ as leachate, AET as actual evapotranspiration and B as balance term.

As visible in Fig. 12, in the case of St. Arnold, 36-65\% of the annual precipitation turns into evapotranspiration.

Figure 12 furthermore demonstratively presents the differences between the three lysimeter basins in terms of leachate and evapotranspiration. While the grassland turns more than half of its annually incoming precipitation into leachate and only $36 \%$ into water vapour, the two forests evaporate more than half of the annual precipitation.

The "balance term" (q.v. Eq. 5) refers to the part of the precipitation neither assignable to leachate nor to AET and is thus presumably attributable to interception as well as water being stored within soil and vegetation. As expected, the forests outbalance the grassland in this regard. Nevertheless, these ratios must be handled with care. The balance term 

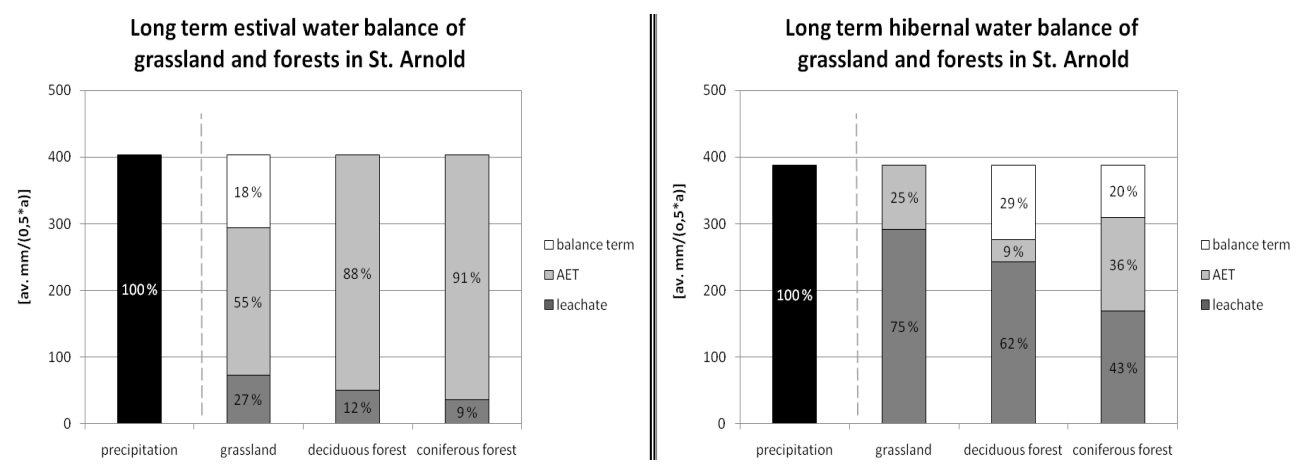

Fig. 13. Long term biannual water balances of grassland (1966-2006) and forests (1980-1999) in St. Arnold.

might also represent inaccuracies concerning precipitation measurement and the parameterisation of the AET. Overall, it is a direct indicator for the bias in the water balance and thus for the uncertainty of this analysis (q.v. Eagleson, 1978). As mentioned above, one of the problems concerning the preciseness of the parameters used for this survey was the lack of information on throughfall and stemflow. Hence, canopy interception could not be determined and gross precipitation data had to be applied for all three basins. For the forests, this provokes a deviation from the real water balance, which certainly figures in the here introduced "balance term". Generally speaking, uncertainties concerning input data, parameterisation of soil dynamics, plant water uptake or soil evaporation (cp. Loos et al., 2007) are a rather common problem in water balance studies and thus also have to be taken in mind for St. Arnold.

The long term biannual water balances for St. Arnold are represented in Figure 13. In comparison to the annual chart (Fig. 12), they show rather strong contrasts in leachate and AET ratios both within individual basins and between seasons. Regarding seasons, the high estival AET rates stand in clear opposition to the considerable hibernal leachate quantities (q.v. Yang et al., 2000), the latter however with exception of the evergreen pine forest. Grassland and deciduous forest thus show similar ratios during winter periods. During summer periods however, the deciduous forest exhibits similar water balance characteristics as the coniferous forest, while leaving the grassland clearly outbalanced in terms of AET quantities.

Examining the biannual balance terms, the relatively high percentages of the forest basins during hibernal seasons stand out. Apart from the abovementioned uncertainties due to the missing interception data, a reason for this might be estival dehydration of the soil due to high water demands during the vegetation period. Subsequently, hibernal re-saturation needs to take place until the soil water retrieves its capacity to contribute to groundwater recharge. In addition to that, according to Jenssen (2008), water storage and consumption on account of litter accumulation and decomposition have to be factored in.

\section{Conclusions}

In this study, the water balance terms of three large scale lysimeter basins with a measuring period of 40 years were analysed. One basin is planted with grassland, the other two with forests, one of which is deciduous, and the other one coniferous. Both systematic differences between the three lysimeter basins and significant long term trends were found. Overall, the grassland basin turns more than half $(53 \%)$ of its annually incoming precipitation into leachate and only $36 \%$ into water vapour, while the deciduous forest exhibits a ratio of $37 \%$ for leachate and $56 \%$ for evapotranspiration, and the evergreen coniferous forest shows the highest evaporation rate $(65 \%)$ and the lowest leachate rate $(26 \%)$.

Regarding generally applicable observations, St. Arnold excellently exemplifies the long term water balance characteristics of the three differently planted lysimeter basins concerning their ratios of leachate and evapotranspiration. During summer periods, the AET rates of the deciduous and the coniferous forest are almost equally high, while the more permeable grassland shows considerably lower rates. During winter periods, leachate becomes prevalent for all basins and groundwater recharge takes place. Yet, the evergreen pine forest continues being subject to a considerable amount of evapotranspiration.

Trends in water balance terms of the three lysimeters are driven by trends of meteorological parameters as well as, in the cases of the forested lysimeters, tree growth. Through the observation period, the air temperature increased (mainly during the hibernal season), relative humidity decreased, global radiation increased and precipitation increased as well. All these factors were potentially influenced by an increase of potential evapotranspiration (PET) and actual evapotranspiration (AET). However, respective evapotranspiration trends were observed only for the two forested lysimeters. At the same time, the grassland lysimeter exhibited a decreasing trend in evapotranspiration. This may have been caused either by the decrease of wind speeds over the years or by the growth of the forest around the grassland basin and the thus increasing sheltering effect. Overall, it can be 
concluded that the trend towards increase of the evapotranspiration dominates for the St. Arnold lysimeter site. Concerning the development of the leachate sums over the years, all basins exhibit long term downward trends, but as a result of the rising tree heights, the leachate quantities of the forests decrease much stronger than those of the grassland. The reason for the general downward trend of the leachate quantities in St. Arnold can be found both in the shelter provided by the surrounding tree populations and by the growth and thus growing shelter and water demand of the tree populations within the lysimeter site.

In terms of long term trends and possible future developments it can be presumed that, due to the pronounced tendencies towards a milder and more humid regional climate (q.v. Leuchs and Bergmann, 2008), evapotranspiration rates in St. Arnold are likely to continue their already existent upward trends, whereas leachate quantities might consequently perpetuate their present downward trends. Possible detriments to this could be vegetational degradation due to either soil dehydration or increasing intense rain events. Other negative influences might be perturbances of the natural litter degradation process and, due to mild hibernal conditions, mass reproduction of insects during vegetation period.

The fundamental idea of lysimetrical and hence water balance research is the transfer of small scale results onto a regional basis in order to obtain universally applicable statements (q.v. Granier et al., 2000). To meet this, a detailed analysis of all the antecedents is of vital importance. Regarding the large-scale lysimeter site St. Arnold, its sheltered position poses an obstacle. Due to the directly adjacent surrounding forests, the wind speed is low and causes evapotranspiration rates to be slightly lower than those presumed under standard conditions (cp. Van Bavel, 1961). A possible circumvention of this problem is the adoption of external wind speed data, as was done for the calculation of potential evapotranspiration (PET) in this survey. Yet, due to the associated uncertainty regarding applications of external data, the actual evapotranspiration (AET) calculated in this survey is based upon internal data.

For future studies in St. Arnold, it would be recommendable to extend the wind speed data collection to an additional measuring point above the forest canopies. Only this would enable an approximation to standard conditions and thus a possible transferability of evapotranspiration data from St. Arnold onto other sites. Another benefit would be the resumption of the LAI measurements as these are of high relevance for the AET calculation using the Penman-Monteith approach.

Acknowledgements. The main part of the data material utilized in this survey was kindly provided by the National Office for the Environment (Staatliches Umweltamt) who also provided access and attendance concerning the lysimeter station St. Arnold. The responsibly for the lysimeter site recently shifted to the North Rhine State Agency for Nature, Environment and Consumer Protection (LANUV), whose support is gratefully appreciated. Further tributes have to be paid to M. Herrmann, S. Holzfuß, C. Keller, C. Lanthaler, M. Matthies, I. Prinz-Tran and D. Zirlewagen for their advice and support, to the German Meteorological Service for providing meteorological data and to J. Master for language-editing the manuscript. The authors also thank four anonymous reviewers that helped to significantly improve the quality of this manuscript.

Edited by: C. De Michele

\section{References}

Albrecht, B.: Großlysimeter-Langzeit-Untersuchungen zur Rückführung von Umkehrosmose- Sickerwasserkonzentrat auf den Deponiekörper von Hausmülldeponien unter, FlushingBedingungen, Dissertation, University Stuttgart, Reports on Waste Management, 80, 88 pp., 2001.

Ayana Gebul, M.: Untersuchungen zum Bodenwasserhaushalt in Abhängigkeit von landwirtschaftlicher Nutzung und auf der Grundlage langjähriger Messungen an der Lysimeterstation in Groß Lüsewitz, Institute for Agricultural Engineering and Urban Water Management, University Rostock, 13-22, 76-90, 2001.

Baldocchi, D.: Stomatal Conductance. Lecture, Ecosystem Science Division, Department of Environmental Science, Policy and Management, University of California, Berkeley, CA, USA, 2006.

Barsch, D. and Flügel, W.-A.: Niederschlag, Grundwasser, Abfluß - Ergebnisse aus dem hydrologisch-geomorphologischen Versuchsgebiet, Hollmuth“, Heidelberg Geographic Papers, Institute for Geography, University Heidelberg, 66, 148-149, 94-98, 1988.

Baumgartner, A. and Liebscher, H.-J.: Allgemeine Hydrologie. Gebrüder Bornträger, Berlin, 1, 462-517, 1990.

Böhm, G.: Die reale Evapotranspiration von Niedermoorgebieten Ermittlung und Parameterisierung nach dem Penman-MonteithKonzept. Dissertation, Faculty of Geosciences, Freie Universität Berlin, 33-51, 4-8, 2001.

Böwer, C.: Die Entwicklung des Klimas in Münster/Westfalen. Graduation Thesis, University Münster, 20-30, 51, 2006.

Böwer, C. and Klemm, O.: Klimawandel - Auch in Westfalen? Landschaftsverband Westfalen-Lippe, Geographische Kommission für Westfalen, Westfalen Regional, 40-41, 2007.

Cislaghi, M., De Michele, C., Ghezzi, A., and Rosso, R.: Statistical assessment of trends and oscillations in rainfall dynamics: Analysis of long daily Italian series, Atmos. Res., 77(1-4), 188-202, 2005.

Eagleson, P. S.: Climate, soil, and vegetation: Introduction to water balance dynamics, Water Resour. Res., 14(5), 705-712, 1978.

Eulenstein, F. and Wenkel, K.-O.: Wasserrückhalt in Agrarlandschaften, Beitrag der Landnutzung an der Versickerung von Wasser zur Grundwasser-Neubildung am Beispiel Mittlerer Fläming, Centre for Investigation on Agriculture and Land Use, Müncheberg, 6-13, 2002.

Fayer, M. J. and Gee, G. W.: Multiple-Year Water Balance of Soil Covers in a Semiarid Setting, J. Environ. Qual., 35(1), 366-377, 2006.

Germer, K.: Bodenwassererfassung in der ungesättigten Zone Vergleich verschiedener Probennahmeverfahren. Diploma Thesis, Institute for Geoecology, Technical University Braunschweig. 22-40, 2004. 
Graf, A., Sulmann, P., Vornholt, G., and Werner, J.: Test of a new measuring configuration for the determination of evapotranspiration in forest stands, Hydrol. Water Resour. Manage., 50(5), 234, 2006.

Granier, A., Biron, P., and Lemoine, D.: Water balance, transpiration and canopy conductance in two beech stands, Agricult. For. Meteor., 100(4), 291-308, 2000.

Häckel, H.: Meteorologie. $4^{\text {th }}$ edition, Eugen Ulmer, Stuttgart, 7071, 182-185, 1999.

Jenssen, M.: Wald- und Forstökosysteme. Lecture, Faculty of Land Use and Nature Conservation, University of Applied Science Eberswalde, Chapter 4, 2008.

Klein, M.: Modellierung des Wasserhaushalts eines Großlysimeters unter Gras. Diploma Thesis, Faculty of Mathematics and Computer Sciences, University Osnabrück, 53-67, 79-90, 1995.

Klein, M.: Langjähriger Wasserhaushalt von Gras- und Waldbeständen - Entwicklung, Kalibrierung und Anwendung des Modells LYFE am Großlysimeter St. Arnold. Dissertation, Faculty of Mathematics and Computer Sciences, University Osnabrück, 6-75, 129-136, 2000.

Ladekarl, U. L.: Soil moisture, evapotranspiration and groundwater recharge in forest and heathland. Aarhus Geoscience, Ph.D. thesis, Faculty of Natural Sciences, University of Aarhus, 11, 21-34, 39-40, 2001.

Lanthaler, C.: Lysimeter Stations and Soil Hydrology Measuring Sites in Europe - Purpose, Equipment, Research Results, Future Developments. Diploma thesis, School of Natural Sciences, Karl-Franzens-University Graz, 96-108, 40-53, 2004.

Lanthaler, C.: Updated information about lysimeter and soil hydrology measuring sites in Europe. European Lysimeter Platform, Austria, 1-5, 2006.

Leuchs, W. and Bergmann, S.: Auswirkungen des Klimawandels auf Grundwasserhaushalt und Wasserversorgung. Scientific Series on water protection, water and sewage, Aachen, 21, 1-17, 2008.

Loos, C., Gaylera, S., and Priesack, E.: Assessment of water balance simulations for large-scale weighing lysimeters. J. Hydrol., 335(3-4), 259-270, 2007.

Milly, P. C. D.: Climate, soil, water storage, and the average annual water balance, Water Resour. Res., 30(7), 2143-2156, 1994.

Möller, M., Stanhill, G. Hydrological impacts of changes in evapotranspiration and precipitation: two case studies in semi-arid and humid climates, Hydrol. Sci. J., 5(6), 1216-1231, 2007.

Montaldo, N., Albertson, J. D., and Mancini, M.: The effect of background hydrometeorological conditions on the sensitivity of evapotranspiration to model parameters: Analysis with measurements from an Italian alpine catchment, Hydrol. Earth Syst. Sci., 7(6), 860, 2003.

Monteith, J. L.: Evaporation and environment (Publ.): The state and movement of water in living organisms, Symposia of the Society for Experimental Biology, Cambridge University Press, 205-234, 1965.

Penman, H. L.: Natural evaporation from open water, bare soil, and grass, Proc. Roy. Soc. London A, 193, 120-146, 1948.

Rapp, J. Regionale Klimatrends in Deutschland im 20. Jahrhundert. Climatic Status Report 2001, German Meteorological Service, 176-183, 2001.

Sahin, A. D.: Statistical analysis of the Angström formula coefficients and application for Turkey, J. Sol. Energy, 62(1), 29-38,
1998.

Salihi, O. O. A.: Potentielle Verdunstung eines Buchen- und Fichtenwaldes auf der Basis von Daten des Deutschen Wetterdienstes als Parameter der aktuellen Evapotranspiration, Dissertation, Faculty of Forestry, University Göttingen, 38-61, 12-17, 1984.

Scanlon, B. R., Levitt, D. G., Reedy, R. C., Keese, K. E., and Sully, M. J.: Ecological controls on water-cycle response to climate variability in deserts, PNAS, 102(17), 6033-6038, 2005.

Schroeder, M.: Die wägbare Lysimeteranlage Senne. Scientific series of the National Board of Water and Waste Management North Rhine-Westphalia Münster, 34, 1973.

Schroeder, M.: Erste Ergebnisse der Großlysimeteranlage St. Arnold bei Rheine, Scientific series of the National Board of Water and Waste Management North Rhine-Westphalia, 65(11), 1975.

Schroeder, M.: Neue Werte zur Grundwasserneubildung unter Wald für das Münsterland, German Memorandum of Hydrology, 27(4), 1983.

Schroeder, M.: Die Interzeptionsmessungen an der Großlysimeteranlage St. Arnold, German Memorandum of Hydrology, 28(56), 1984.

Schroeder, M. Jahreswerte der Waldverdunstung und ihrer Teilgrößen an der Großlysimeteranlage St. Arnold, German Memorandum of Hydrology, 31(1), 1987.

Schroeder, M.: 15 Jahre Messungen an der Großlysimeteranlage St. Arnold. Scientific series of the National Board of Water and Waste Management North Rhine-Westphalia, 44, 1988.

Schroeder, M.: Interzeptionsmessungen an der GroßlysimeterAnlage St. Arnold in den Jahren 1984 bis 1987 und die Extrapolation der Messwerte mit Hilfe eines Rechenmodells, German Memorandum of Hydrology, 33(2), 1989.

Schroeder, M.: Verdunstung von Land- und Wasserflächen in St. Arnold bei Rheine in den Jahren 1980-1987, German Memorandum of Hydrology, 34(4), 1990.

Schroeder, M. Messergebnisse der Jahre 1979 bis 1985 an der wägbaren Lysimeteranlage Senne. Scientific series of the National Board of Water and Waste Management North RhineWestphalia, Düsseldorf, 48, 11-19, 1991.

Schroeder, M.: 25 Jahre Großlysimeteranlage St. Arnold. Office for the Environment Münster, 1-11, 13-15, 19-21, 28, 1992.

Sevruk, B.: Methodische Untersuchungen des systematischen Messfehlers der Hellmann-Regenmesser im Sommerhalbjahr in der Schweiz, Memorandum of Hydraulic Engineering, Hydrol. Glaciol., 52, Zürich, 1981.

Steiner, J. L., Howell, T. A., and Schneider, A. D.: Lysimetric evaluation of daily potential evapotranspiration models for grain sorghum. Agronomy J., 83, 240-247, 1991.

Stephenson, N. L.: Climatic control of vegetation distribution: the role of the water balance, The American Naturalist, 135, 649, 1990.

Van Bavel, C. H. M.: Lysimetric measurements of evapotranspiration rates in the eastern U.S., Soil Sci. Soc. Am. J., 25, 138-141, 1961.

Vesala, T., Hämeria, K., and Ahonena, T.: Experimental and numerical analysis of stomatal absorption of sulphur dioxide and transpiration by pine needles, J. Atmos. Environ., 29, 825-836, 1995.

Weischet, W. Einführung in die allgemeine Klimatologie, 6th edition, Gebrüder Borntraeger publishing house, Stuttgart, 150- 
167, 101-109, 2002.

Weritz, F. "In Münster regnet's..." - Häufigkeitsverteilung des Niederschlags in Münster im bundesweiten Vergleich, Thesis, University Münster. 32-40, 2007.

Werner, J.: Die Erprobung einer vereinfachten energetischen Verdunstungs-Bestimmungsmethode an den Waldbeständen der Großlysimeteranlage St. Arnold bei Rheine 1981/82. Scientific series of the National Board of Water and Waste Management North Rhine-Westphalia, Düsseldorf, 40, 17-25, 1985.

Wesseling, B., Feddes, J. G., and Belmans, C.: Soil Acidification and Solute Budgets for Forested Lysimeters in NordrheinWestfalen, J. Plant Nutr. Soil Sci., 154(3), 1991.

Yang, J., Li, B., and Liu, S.: A large weighing lysimeter for evapotranspiration and soil water-groundwater exchange studies, Hydrol. Proc., 14, 1887-1897, 2000.
Zenker, T.: Verdunstungswiderstände und Gras-Referenzverdunstung - Lysimeteruntersuchungen zum Penman-Monteith-Ansatz im Berliner Raum. Dissertation, Faculty of Architecture, Environment and Society, TU Berlin, 56-74, 20-28, 2003.

Zirlewagen, D.: Transpiration, Bodensaugspannung und Versickerung - entscheidende Kenngrößen für den Wasserhaushalt von drei typischen Waldbeständen. Report on the ecological state of the forest, Interra, Konzingen. 30-33, 2002.

Zmarsly, E., Kuttler, W., and Pethe, H.: Meteorologischklimatologisches Grundwissen, 2nd edition, Eugen Ulmer, Stuttgart, 131-134, 72, 2002. 